\title{
TINJAUAN FILSAFAT PENDIDIKAN IBN MISKAWAIH TERHADAP FENOMENA KENAKALAN REMAJA
}

\author{
Oleh: \\ Zulkifli Safri \\ Alumnus Fakultas Filsafat UGM Yogyakarta
}

\begin{abstract}
Abstrak
Penilitian ini berjudul "Tinjauan Filsafat Pendidikan Ibn Miskawaih terhadap Fenomena Kenakalan Remaja". Penelitian dilatarbelakangi permasalahan kenakalan remaja di masyarakat yang semakin banyak. Tujuan penelitian ini memahami konsep pendidikan Ibn Miskawaih yang menawarkan solusi terhadap kasus kenakalan remaja. Penelitian merupakan studi kepustakaan menggunakan metode hermeneutika filosofis. Sumber primer dan sekunder diteliti dengan menggunakan unsur-unsur metodis antara lain deskripsi, interpretasi, dan refleksi filosofis. Objek material dalam penelitian adalah fenomena kenakalan remaja. Objek formalnya adalah filsafat pendidikan Ibn Miskawaih. Hasil penelitian yang dicapai ialah: pertama, memetakan fenomena kenakalan remaja. Kedua, tinjauan filsafat pendidikan Ibn Miskawaih terhadap fenomena kenakalan remaja. Filsafat pendidikan Ibn Miskawaih dapat diketahui bahwa fenomena kenakalan remaja dapat dicegah ataupun diselesaikan dengan pembinaan karakter. Syariat agama merupakan kunci utama dalam hal ini. Disertai dengan pendidik teladan dalam keluarga dan masyarakat.
\end{abstract}

\section{Kata Kunci: Filsafat Pendidikan Ibn Miskawaih, Kenakalan, Remaja}

\section{A. Pendahuluan}

Era internet sekarang ini informasi tumpah ruah dalam keseharian. Tidak jarang informasi tersebut berisi konten-konten kekerasan atau pornografi melibatkan remaja. Melalui internet pula para remaja sangat mudah mencontoh perilaku buruk remaja lain yang terekam kamera. Karena sudah naluriah bahwa manusia lebih mudah meniru 
perilaku seseorang dibanding mendengarkan petuah-petuah bijak. Sehingga perlu memfilter segala bentuk kegiatan yang mengarahkan remaja pada kenakalan remaja. Filter yang diperlukan salah satunya melalui pendidikan. Pendidikan menjadi tempat penanaman nilai-nilai luhur. Bagi para remaja nilai-nilai luhur berguna bagi kehidupan mendatang.

Pendidikan merupakan alat penting untuk mengubah sikap dan tindakan seseorang. Pendidikan yang kurang baik, akan menciptakan anak didik yang kurang baik pula, begitupun sebaliknya. Sehingga remaja-remaja perlu mendapatkan perhatian khusus dalam pendidikanya. Sudah ada banyak teori-teori yang dilahirkan rahim pemikiran Barat. Bahkan sebagian besar pendidikan disekolah-sekolah berkiblat ke Barat. Sebagai umat muslim ada baiknya kalau kembali melirik konsep-konsep pendidikan yang ditawarkan oleh pemikir-pemikir Islam terkemuka.

Salah satu pemikir Islam terkemuka itu adalah Ibn Miskawaih. Boleh dikata Ibn Miskawaih kurang terkenal dibanding pemikir lain seperti Ibn Sina dengan ilmu kedokterannya, Ibn Khaldun dengan teori-teori sosialnya dan Al Ghazali dengan Tahafut Al Falasafiah dan Ibn Arabi sebagai guru kedua karena mengomentari buku-buku karangan Aristoteles dibidang filsafat. Sedangkan Ibn Miskawaih dikenal melalui ajaran etikanya dalam berbagai karyanya. Salah satu karyanya yang monumental dan dianggap sebagai masterpiece adalah Tahdzib Al-Akhlaq. Walaupun tema utama dalam Tahdzib Al-Akhlaq sebagian besar adalah etika. Tetapi untuk merumuskan filsafat pendidikan Ibn Miskawaih dapat dilakukan, karena berangkat dari asumsi bahwa pendidikan dalam Islam berdasarkan pada perbaikan akhlaq manusia. Sesuai dengan seruan Allah SWT dan Rasulnya. Literatur-literatur Barat pun beranggapan demikian bahwa pendidikan menjadikan manusia agar memiliki karakter yang lebih baik.

Menurut Ali Saifullah dalam (dalam Dra. Zuhraini, 1995: 13) menjabarkan bahwa filsafat pendidikan memusatkan perhatiannya pada dua fungsi tugas normatif yaitu kegiatan merumuskan dasar-dasar, dan tujuan-tujuan pendidikan, konsep tentang hakikat manusia, serta persepsi hakikat dan segi-segi pendidikan serta isi moral pendidikannya. Kemudian merumuskan sistem atau teori pendidikan (science of education) yang meliputi politik pendidikan, kepemimpinan pendidikan atau organisasi pendidikan. ${ }^{i}$ Acuan inilah yang dapat dijadikan garis penghubung untuk menarik konsep-konsep filsafat pendidikan 
dalam Tahdzib Al-Akhlaq Ibn Miskawaih yang diterapkan kedalam pendidikan remaja yang bertujuan perbaikan akhlaq sesuai dengan tuntunan Allah dan Rasulnya.

\section{B. Riwayat Hidup dan Karya-Karya Ibn Miskawaih}

Ibn Miskawaih dilahirkan di Ray tahun 421 Hijriah dengan nama asli Abu Ahmad bin Ya'kub. Masa hidupnya di habiskan untuk mengabdi pada Dinasti Buwaihiyah. Hal ini dapat dilihat dari pengabdiannya pada Al-Muhallabi wazir dari dinasti Buwahiyah. Kemudian pada Ibn Al-Amid hingga putranya Abu Al-Fath. Ibn Miskawaih meninggal tahun $421 \mathrm{H}(1030 \mathrm{M})$.

Ibn Miskawaih merupakan seorang pemikir Islam yang banyak menghasilkan karyakarya terkemuka. Salah satu karyanya yang monumental adalah Tahdzib Al-Akhlaq. Bahkan pengantar yang diberikan oleh Ibn Al-Khatib menyebutkan diantaranya karyanya yang lain Tajarib Al-Umam, Ta'qub Al-Himam, Thaharat Al-Nafs, Adab wa Al-Firs, Al-Faws Al-Ashgar fi Ushul Al-Dinayat Al-Akbar (dalam bidang etika), Kitab Al-Siasat, Muhktar AlAsyar, Nadim Al-Farid, Nuzhat Namah 'Alaiy (dalam bahasa Persia, yang ditulisnya atas nama "Ala Daulah Al-Dailamiy), Jawidan Khird (juga dalam bahasa Persia), Tartib AlSa;dat (dalam bidang etika), Al-Adwiyah Al-Mufridah (tentang obat-obatan yang bermanfat dalam bidang kedokteran), Al-Asyribah (mengenai minuman) (Miskawaih, 1999: 29).

Ada tuduhan yang ditujukan pada Ibn Miskawaih bahwa dulunya dirinya adalah penganut Majusi. Tetapi pendapat seperti ini patut dikesampingkan mengingat bahwa latar belakangnya tersebut. Kalau memang benar tidak menjadi soal sebab Ibn Miskawaih telah memeluk agama Islam dan memberikan sumbangsih besar bagi dunia pemikiran Islam. Ibn Miskawaih seperti halnya pemikir-pemikir di masanya menekuni berbagai bidang ilmu. Mulai dari ilmu kedokteran, sastra, logika dan filsafat, karena pada masa itu ilmu tidaklah terbagi seperti sekarang. Sehingga dalam karyanya Tahdzib Al_Akhlaq dijumpai cabangcabang ilmu lain dan berujung pangkal pada aqhlak.

Salah satu cara memahami pemikiran seorang filsuf adalah dengan mengetahui pemikir-pemikir yang memengaruhinya. Ibn Miskawaih dipengaruhi oleh pemikir-pemikir Yunani seperti Aristoteles, Galen, Bryson (salah satu tokoh Neo-Phytogorean). Tetapi tidak boleh dikesampingkan bahwa sumber utama ajaran Islam Al-Quran dan Hadis sebagai 
dasar utama pemikirannya. Miskawaih dikenal sebagai filsuf moral karena sebagian besar karyanya tentang perbaikan moral seseorang untuk menuju kebahagian. Perbaikan moral tersebut sesuai dengan prisip-prinsip dalam Al-Quran. Kehidupan yang menuntut umat Islam mendaptkan rahmat-Nya. Serta di akhirat mendapatkan surga yang telah dijanjikan Allah SWT.

\section{Pemikiran Filsafat Pendidikan Ibn Miskawaih}

\section{Filsafat Pendidikan Islam}

Pendidikan merupakan suatu proses yang melibatkan segala bentuk fakultas dalam diri seseorang baik itu pikiran dan perasaan mengarahkan manusia pada kehidupan yang lebih baik. Proses ini bertujuan membentuk kemampuan dasar seseorang dalam menjalani kehidupan. Sementara filsafat secara umum diartikan sebagai suatu proses pencarian hakiki atas pertanyaan tentang manusia, alam dan dunia menggunakan akal pikiran. Kaitan antara filsafat dan pendidikan terletak hasil-hasil pemikiran spekulatif filsafat atas realitas sebagai kerangka acuan dalam lapangan pendidikan. Filsafat sebagai suatu kegiatan berpikir berusaha mempertanyakan kembali bangunan-bangunan teori pendidikan, sembari mencarikan jawaban atas pertanyaan tersebut. Maka filsafat pendidikan berusaha mengecam proses pendidikan mengubahnya, dan berusaha untuk menjelaskan dan menerangkannya supaya pengalaman kemanusian ini sesuai dengan kehidupan baru (Al-Syaibany, 1979: 30).

Filsafat yang memiliki tinjauan yang begitu luas sejalan dengan salah satu cirinya yang bersifat komprehensif, memberikan manusia suatu pandangan hidup. Tetapi perlu dingat bahwa pandangan hidup ini berbeda-beda dalam suatu masyarakat. Misalnya saja antara pandangan hidup orang di Barat dan orang di Timur. Bagi orang-orang di Barat alam itu harus dikuasai (eksploitasi) sementara bagi orang-orang di Timur hidup itu selaras dengan alam. Walaupun perbandingan ini terlalu ekstrem dan tidak selalu berlaku seperti itu. Setidaknya gambaran ini mempermudah memahami cara kerja pandangan hidup manusia. Perbedaan pandangan hidup berarti membedakan juga cara mengatasi dunia. Adapun perbedaan dalam sistem pendidikan, tampaknya ikut dipengaruhi oleh cara pandang (world view) dari setiap masyarakat, kelompok atau bangsa masing- 
masing...Sebab bagaimana pun pandangan hidup ini mencerminkan jati diri yang harus dipertahankan serta dikembangkan dan selanjutnya diwariskan kepada generasi muda masyarakat bersangkutan (Jalaluddin, 2001: 67).

Bagi masyarakat muslim nilai-nilai itu bersumber dari Al-Quran dan Hadis. Sehingga world view harus sesuai dengan tuntunan didalam Al-Quran dan Hadis. Filsafat pendidikan islam dapat diartikan sebagai studi tentang pandangan filosofis dari sistem dan aliran filsafat dalam islam terhadap masalah-masalah kependidikan dan bagaimana pengaruhnya terhadap pertumbuhan dan perkembangan manusia Muslim dan umat Islam (Hamdani-Fuad, 1998: 22). Jelasnya, Al-Quran dan Sunah adalah dasar dan landasan bagi filsafat pendidikan Islam, menjadi standar kebenaran bagi hasil pemikiran filosofis manusia untuk diamalkan dalam kehidupan (Hamdani-Fuad, 1998: 27).

Nilai-nilai dalam Al-Quran dan Hadis ini untuk diterapkan mestilah melalui sebuah proses. Agar dalam pendidikan nantinya dicapai hasil yang maksimal, sehingga perlu merumuskan faktor-faktor penting dalam proses penanaman nilai-nilai tersebut. Adapun pola dan sistem pemikiran filosofis kependidikan yang berdimensi mikro adalah yang menyangkut proses pendidikan yang meliputi tiga faktor, yaitu

a) Pendidik

b) Anak didik, dan

c) Alat-alat pendidikan, baik yang bersifat materiil maupun non materiil (Arifin, 2009: 8) .

Sedangkan tujuan yang hendak dicapai adalah terbentuknya kepribadian yang bulat dan utuh sebgai manusia individual dan sosial serta hamba Tuhan yang mengabdikan diri kepada-Nya (Arifin, 2009: 8).

\section{Filsafat Pendidikan Ibn Miskawaih}

Ibn Miskawaih memfokuskan pembahasanya pada akhlaq. Ibn Miskawaih mengikuti pendapat Aristoteles bahwa segala sesuatu yang dilakukan manusia berujung pangkal pada kebahagiaan. Teori pendidikan Ibn Miskawaih didasarkan pada teori pendidikan Aristoteles yang menekankan segi intelektual, kejiwaan dan pendidikan moral yang ditujukan pada upaya melahirkan manusia yang baik menurut pandangan masyarakat dan agar mencapai kebahagian hidup yang abadi dan mengamalkannya 
dengan dirinya (Alavi, 2003: 50). Ibn Miskwaih lebih mengkerucutkan lagi bahwa kebahagiaan dapat dicapai dengan memperbaiki akhlaq. Pemikiranya itu terangkum penuh dalam karya Tahdzib Al-Akhlaq. Buku Tahdzib Al-Akhlaq membahas bidang lain pula, tetapi tetap pada pengarahan pada perbaikan Akhlak. Penulis akan berfokus pada wacana kedua dalam buku ini. Ibn Miskawaih banyak membahas konsep pendidikannya disini, tanpa mengabaikan wacana lain yang berhubungan.

\section{Perbaikan Karakter sebagai Suatu Cara}

Ibn Miskawaih memulai rumusannya menuju kebahagian melalui pendidikan karakter. Baginya karakter (khuluq) merupakan suatu keadaan jiwa. Keadaan ini menyebabkan jiwa bertindak tanpa dipikir atau dipertimbangkan secara mendalam. Keadaan ini ada dua jenis. Yang pertama, alamiah dan bertolak dari watak. Misalnya pada orang-orang yang gampang sekali marah karena hal yang paling kecil, atau yang takut menghadapi insiden yang paling sepele. Yang kedua, tercipta melalui kebiasaan dan latihan. Pada mulanya keadaan ini terjadi karena dipertimbangkan dan dipikirkan, namun kemudian, melalui pratek terus menerus, menjadi karakter (Miskawaih, 1999: 56) Sehingga harus dari sedini mungkin melakukan pendidikan kepada anak dan remaja.

Ibn Miskawaih dalam konsep pendidikannya memiliki kemiripan dengan konsep John Locke. Keduanya sama-sama beranggapan bahwa anak secara natural tidak baik dan tidak buruk. Singkatnya anak itu tidak bersalah. Pemikiran seorang anak tak ubahnya seperti batu tulis yang bersih sejak lahirnya, dimana di atas batu itu kita dapat menulis apa yang kita mau (Alavi, 2003: 51). John Locke menyebut keadaan ini dengan istilah tabula rasa (kertas kosong). Tetapi dalam hal ini "menulis apa yang kita mau" dalam istilah Ibn Miskawaih difokuskan pada perbaikan moral, bukan pada kemampuan yang bersifat bawaan secara biologis. Sehingga menurut Ibn Miskawaih pendidikan karakter ini harus sejalan dengan syariat agama yang merupakan faktor untuk meluruskan remaja, membiasakan mereka untuk melakukan perbuatan yang baik, sekaligus yang mempersiapkan diri mereka untuk menerima kearifan, mengupayakan kebajikan, dan mencapai kebahagiaan melalui berpikir dan penalaran yang akurat (Miskawih, 1999: 59$60)$. 


\section{Pendidik Dalam Mendidik}

Ibn Miskawaih mengatakan bahwa yang perlu ditanamkan pada diri anak dan remaja pertama kali adalah rasa malu. Sesuai dengan salah satu hadis Rasulullah dari Abu Mas'ud radhiyallahu 'anhu, Rasulullah shallallahu 'alaihi wasallam bersabda,

"Sesungguhnya sebagian ajaran yang masih dikenal umat manusia dari perkataan para nabi terdahulu adalah: 'Bila kamu tidak malu, berbuatlah sesukamu." (HR. Al Bukhari) Tanda pertama yang ada pada anak kecil, dan sekaligus tanda bahwa dia mempunyai akal pikiran, adalah rasa malu. Rasa malu ini menunjukkan bahwa dia telah mulai mengetahui apa-apa yang buruk. Lalu dia akan berusaha menghindari dan bahkan khawatir kalaukalau dia terperosok ke dalam keburukan tersebut (Miskawaih, 1999: 75).

Rasulullah menekankan bahwa melakukan sesuatu sesuka hati dapat merugikan orang lain. Seseorang yang melakukan sesuka hati tanpa rasa malu tidak menghiraukan aturan-aturan yang disepakati baik dalam masyarakat dan agama. Orang-orang seperti ini layaknya seperti hewan mengandalkan insting bertahan hidup tanpa memperhitungkan bahwa ada pula aturan moral yang mengikat manusia. Seandainya makan hanya untuk makan mungkin panti asuhan tidak diketemukan dalam masyarakat. Karena setiap orang sibuk mengisi perut masing-masing sudah memikirkan lagi orang lain kesusahan disekitarnya, yang butuh makanan tetapi tidak dapat mencari rezeki sendiri disebabkan keterbatasan fisik.

Anak jiwanya perlu ditempa dengan aturan-aturan moral. Karena jiwa anak kecil masih sederhana dan belum menerima gambar apapun, juga belum mempunyai pendapat atau tekad yang akan mengubahnya dari satu hal ke lain hal. Sebab itu, kalau jiwanya telah menerima gambar tertentu, anak ini akan tumbuh sesuai dengan gambar itu dan terbiasa dengan gambar itu (Miskawaih, 1999: 75). Anak yang terbiasa atau diawal-awal masa pertumbuhannya dipoles dengan kebiasaan buruk akan melekat dalam dirinya perbuatan tersebut. Maka harus diupayakan agar jiwa seperi itu mencintai kemuliaan, terutama yang datang dari agama, bukan yang dating melalui uang. Dan usahakan agar dia sebisa mungkin, membiasakan diri melaksanakan kewajiban agama (Miskawaih, 1999: 76). 
Ibn Miskawaih menekankan bahwa pendidikan awal bagi anak itu adalah dalam rumah tangga, yang dilakukan oleh orang tuanya sendiri. Ibn Miskawaih dalam Tahdzib AlAkhlaq sangat detail cara mendidik anak mulai dari berpakaian, akhlak di meja makan, memotong makanan, jenis makanan yang disantap anak, adab membuang ingus dan meludah dan larangan meluarkan sumpah serapah. Peran sebuah instusi pemerintah juga penting, yang dalam istilah Ibn Miskawaih "kewajiban pemuka masyarakat". Ada dua hal yang mesti dilakukan secara institusi disini. Pertama, melusruskan mereka melalui ilmuilmu rasional, dan kedua, memandu mereka menuju disiplin-disiplin praktis dan aktivitas intelektual (Miskawaih, 1999: 87).

Ibn Miskawaih selanjutnya mengajurkan pada pendidik agar selalu memberikan penghormatan dan pujian kepada anak. perlunya dialkukan hal seperti itu agar anak-anak tetap terpacu dan senang melakukan kebaikan. Anak-anak pun akan merasa dihargai dengan usaha yang dilakukannya. Bila suatu ketika anda dapati dia melakukan perbuatan yang bertolak belakang dengan apa yang kami ungkapkan ini, maka yang pertama kali harus anda lakukan adalah jangan cerca dia! juga jangan anda katakan terus terang padanya bahwa dia telah melakukan perbuatan buruk. Pura-puralah tak memperhatikannya, seolah-olah dia tidak sengaja melakukan hal itu; atau bahkan katakan saja sebetulnya hal itu bukan kehendaknya. Ini khususnya diperlukan bila anak menutupnutupinya, atau bersikeras menyembunyikan dari mata umum apa yang telah dilakukannya itu. Kalaupun kemudian dia melakukannya lagi, maka diam-diam celalah (Miskawaih, 1999: 77).

\section{Mencapai Derajat Manusia Utama}

Ibn Miskawaih mengarahkan konsep pendidikannya menjadi manusia paripurna sesuai dengan Al-Quran- Hadis. Bahkan menurutnya ketika manusia meninggalkan alam manusianya. Manusia menuju alam malaikat yang memiliki derajat yang lebih tinggi dan utama yaitu pada saat seluruh mujud bersatu, dan awal mereka bersatu dengan akhir mereka dan sebaliknya. Inilah yang disebut lingkaran eksistensi, karena lingkaran ini didefiniskan sebagai satu garis yang geraknya bermula dari satu titik, lalu berakhir segaligus pada titik itu lagi. Lingkaran eksistensi merupakan lingkaran yang membuat persatuan dari kebhinekaan yang merupakan dalil kuat tentang keesaan, kearifan, 
kekuasaan dan kemuliaan Penciptanya Yang Mahamulia nama-Nya, Mahatinggi kebaikannya-Nya, dan Mahasuci sebutan-Nya (Miskawaih, 1999: 85).

Untuk mencapai tingkatan di alam malaikat mestilah sejalan dengan pendidikan moral yang telah dikonsepkan Ibn Miskawaih diawal-awal tulisan ini. Sangat sulit bagi manusia untuk bertumbuh moralnya secara alami tanpa adanya bimbingan dari luar dirinya. Sesuatu yang berasal dari luar diri seperti pisau bermata dua memiliki kebaikan dan keburukan. Kebaikan itu dapat diketahui melalui perintah agama yang termaktub dalam Al-Quran. Kalau anda sudah mencapai tahap ini, maka anda sudah siap menerima anugerah Allah SWT. Rahmat-Nya akan dating pada anda, dan anda akan bebas dari gejolak nafsu hewani (Miskawaih, 1999: 85).

Diutusnya nabi dan Rasul merupakan salah satu acuan bahwa manusia pada fitrahnya memerlukan pendidikan untuk meluruskan jalan hidupnya sesuai dengan perintah Allah SWT. Nabi dan Rasul ini sebagai pemandu jalan dan pendidik. Karena tabiat-tabiat mulia manusia yang dapat menuju kebahagiaan dengan sendirinya dan tak perlu bantuan, sulit didapat. Bahkan sebetulnya tabiat seperti itu tidak ada, kecuali (dan ini jarang) setelah melewati waktu dan periode yang panjang (Miskawaih, 1999: 87). Dalam hal yang bernilai duniawi setiap orang memiliki tingkat kebahagian. Tetapi kebahagian yang bersifat spiritual kebahagian semua orang sama yang menurut Ibn Miskawaih kebahagiaan puncak, yang tak ada lagi kebahagiaan setelah itu (Miskawaih, 1999: 87). Semua kebahagian itu dicapai dengan penjernihan diri dengan mendekatkan diri kepada Allah SWT. Manusia yang mendekat diri pada Allah adalah manusia-manusia yang mengikuti tarbiyah langsung dariNya. Tarbiyah ini dilakukan secara terus menerus sepanjang hidup manusia. Hasil akhir dari pendidikan diri ini dibalas langsung oleh Allah SWT di hari akhir kelak.

\section{Kenakalan Remaja}

Kata remaja berasal dari bahasa latin adolescere yang berarti tumbuh untuk mencapai kematangan atau dalam perkembangan menjadi dewasa (Ali.M dan Asrori.M, 2006:9). Remaja merupakan proses seorang anak menuju masa dewasa dengan rentan umur 12 tahun hingga 21 tahun. Masa-masa ini boleh dikatakan lumayan urgen bagi seorang anak. Kontrol orang tua tidak penuh lagi, mengingat bahwa anak-anak dimasa transisi ini 
separuh waktunya berada di luar rumah bertemu dan bersentuhan dengan lingkungan berbeda.

Masalah timbul ketika remaja yang kurang mendapatkan perhatian khusus dari keluarga dipengaruhi buruknya lingkungan diluar dirinya, atau juga dari keluarga itu sendiri. Dari sinilah sering muncul kenakalan remaja. Bahkan menurut Hawari berdasarkan hasil beberapa penelitian ditemukan bahwa salah satu faktor penyebab timbulnya kenakalan remaja adalah tidak berfungsinya orangtua sebagai figur tauladan bagi anak (Hawari, 1997).

Menurut Fuhrmann (1990) kenakalan remaja adalah suatu tindakan anak muda yang dapat merusak dan mengganggu, baik terhadap diri sendiri maupun orang lain. Kenakalan remaja seringkali melanggar hukum yang ada. Kasus kekerasan, bullying, tawuran antar sekola, penggunaan narkoba dan seks bebas. Kenakalan remaja akhirnya menjadi tanggungjawaba bersama.

Kenakalan remaja menurut Kartini merupakan produk sampingan dari:

a. Pendidikan massal yang tidak menekankan pendidikan watak dan kepribadian anak

b. Kurangnya usaha orang tua dan orang dewasa menanamkan moralitas dan keyakinan Bergama pada anak muda

c. Kurang ditumbuhkannya tanggung jawab sosial pada anak-anaka remaja (Kartono, 2010: 12)

Penyebab kenakalan remaja menurut Willis dibagi atau dikelompokkan berdasarkan tempat atau sumber kenakalan remaja terdapat empat bagian.

1. Faktor-faktor di dalam diri anak itu sendiri, yaitu predisposing factor, lemahnya pertahanan diri, kurangnya kemampuan penyesuaian diri, dan kurangnya dasardasar keimanan di dalam diri remaja.

2. Faktor-faktor di lingkungan rumah tangga, yaitu remaja kurang mendapatkan kasih sayang dan perhatian dari orang tua, lemahnya keadaan ekonomi orang tua (terutama didesa-desa), dan kehidupan keluarga yang tidak harmonis.

3. Faktor-faktor yang berasal dari lingkungan masyarakat, yaitu kurangnya pelaksanaan ajaran-ajaran agama secara konsekuen, masyarakat yang kurang 
memperoleh pendidikan, kurangnya pengawasan terhadap remaja, dan pengaruh norma-norma baru dari luar.

4. Faktor-faktor yang berasal dari lingkungan sekolah, yaitu guru, faktor fasilitas pendidikan, norma-norma pendidikan dan kekompakan guru, dan kekurangan guru (Willis, 2008: 92).

\section{E. Membangun Karakter Remaja Melalui Syariat Agama}

Ibn Miskawaih dalam Tahdzib Al-Akhlaq menganggap bahwa dasar pembentukan karakter manusia dari masa anak-anak. Anak-anak akan melalui fase remaja yang bersinggungan dengan dunia luar. Pembentukan karakter menjadi tameng menghadapi nilai-nilai yang saling memengaruhi. Sadar atau tidak kemunculan media sosial menjadi alat pertarungan nilai dan berebut pengaruh. Remaja mudah saja terpengaruh hal-hal buruk di media sosial. Remaja meniru segala tindak tanduk idolanya. Anggaplah idola remaja tersebut seorang artis lelaki memiliki badan penuhi tato dan menggunakan narkoba viral melalui video. Artis ini memberikan pendapatnya tentang kenikmatan menggunakan narkoba. Remaja yang menonton video tersebut dapat tergugah pula menggunakan narkoba. Kehidupan artis dan remaja yang mengikuti cara hidup ini dapatlah digolongkan seperti dikatakan Ibn Miskawaih sebagian orang yang menduga bahwa kesempurnaan dan tujuan hidup manusia ada pada kenikmatan inderawi (Miskawaih, 1999: 65). Kenikmatan seperti ini hanya bersifat sementara. Apabila remaja sudah terperangkap pada cara pandang yang mengutamakan kenikmatan inderawi, maka besar kemungkinan terjerumus dalam kenakalan remaja.

Ibn Miskawaih mengajukan sebuah jalan keluar dengan memberikan pembinaan karakter. Baginya syariat agama merupakan faktor yang meluruskan karakter remaja yang membiasakan mereka untuk melakukan perbuatan baik, sekaligus yang mempersiapkan diri mereka untuk menerima kearifan, mengupayakan kebajikan, dan mencapai kebahagiaan melalui berpikir dan penalaran yang akurat (Miskawaih, 1999: 65). Berpikir dan penalaran akurat yang dimaksud Ibn Miskawaih adalah memikirkan segala bentuk keEsa-an Allah dan memahami akibat dari melanggar perintah Allah. Proses membentuk karakter remaja dengan penggemblengan syariat agama dilakukan terus menerus. Dalam 
penyusunan tatanan moral, dan dalam mengarahkannya ke kesempurnaannya setapak demi setapak, kita dihadapkan pada cara yang alami, yaitu dimana kita mengikuti proses alami(Miskawaih, 1999: 60).

Pengajaran syariat agama secara maasif pada remaja akan membentuk jiwanya. Jiwa yang perlu dibentuk menurut Ibn Miskawaih terbagi menjadi tiga. Pertama, jiwa yang pada pembawaanya mulia dan bermoral adalah jiwa berpikir. Kedua, jiwa tak bermoral, namun tak dapat menerima tatanan moral, itulah jiwa binantang. Ketiga, jiwa yang tak bermoral namun mampu menerima dan mengikuti moral, inilah jiwa amarah (Miskawih, 1999: 72). Ketiga jiwa ini harus seimbang dikomandoi jiwa berpikir untuk mengatur fakultas jiwa yang lain. Perangkap kenikmatan inderawi memuluskan jalan jiwa binatang untuk unggul dari jiwa berpikir dan jiwa amarah.

Kalau orang didik sejak kecil untuk mengikuti syariat agama, untuk mengerjakan kewajiban-kewajiban syariat, sampai dia terbiasa (Miskawaih, 199: 70). Pembiasaan dalam ajaran moral Ibn Miskawaih merupakan hal pokok. Ibn Miskawaih sendiri sudah melakukan pelatihan ini sebelumnya. Ibn Miskawaih mengatakan bahwa perlu diketahui, bahwa saya, setelah beranjak dewasa dapat menjauhkan diri dari hal-hal yang buruk ini, melalui perjuangan keras dan berat. Mudah-mudahan Anda, wahai pencari kemuliaan dan keutamaan moral dapat berhasil seperti saya (Miskawaih, 1999: 71).

Kesempurnaan karakter dimulai dari menertibkan fakultas-fakultas dan aktivitas yang khas bagi fakultas-fakultas itu hingga tidak saling berbenturan, namun hidup harmonis di dalam dirinya, hingga seluruh aktivitasnya sesuai dengan fakultas lainnya dan tertata dengan baik (Miskawaih, 1999: 63). Karakter remaja yang dibina melalui syariat agama mengarah kepada ketinggian spiritual. Jiwa berpikirnya menjadi penuntun dalam kehidupan, membentuk dirinya menjadi remaja yang memiliki ketinggian moral. Setiap kebajikan yang dikerjakannya dipenuhi keihlasaan karena sudah memfokuskan dirinya pada segala bentuk maujud.

Menurut (Miskawaih, 1999: 80) perlu membiasakan remaja mengekang diri dari rayuan hawa nafsunya yang senantiasa menggodanya, serta bisa menjaga diri agar tidak hanyut oleh kenikmatan, atau banyak memikirkannya. Ujung pangkal dari pembentukan karakter Ibn Miskawaih adalah pembentukan manusia filosof. 


\section{F. Menjadi Pendidik Teladan}

Salah satu fitrah manusia adalah mengimitasi atau meniru. Banyak hal yang dikerjakan manusia dalam hidup merupakan hasil tiruan dari manusia dimasa lalu. Kenakalan remaja muncul pula sebagai bentuk imitasi atas perilaku seseorang yang dianggap remaja sebagai bentuk ideal sesuatu yang sebenarnya buruk. Proses imitasi perilaku tidak memandang baik atau buruknya suatu perilaku. Remaja mengimitasi suatu perilaku saat perilaku itu dianggap berguna dalam pergaulan sehari-harinya.

Proses imitasi berjalan dengan baik, jika yang mencontohkan perilaku tersebut memiliki pengaruh di tempat tertentu. Maka dalam membina karakter remaja ada baiknya diikuti contoh secara langsung. Misalnya remaja diajak untuk menjauhi rokok, harusnya yang mengajak pun tidak merokok pula. Ketika dibawa dalam ranah moral, hal ini dicontohkan oleh Nabi Muhammad SAW mendidik dan mengajar dengan perilaku kepada para sahabatnya. Allah SWT berfirman Q.S As-Saff ayat 3 berbunyi:

"Amat besar kebencian di sisi Allah bahwa kamu mengatakan apa-apa yang tidak kamu kerjakan"

Menurut Ibn Miskawaih dalam mendidik selalu utamakan pujian daripada celaan. Remaja merasa senang dengan pujian karena merasa dihargai. Celaan membuat remaja sulit untuk mengembangkan diri. Selalu muncul kekhawatiran takut salah dan tidak berani mencoba. Kedua hal ini memiliki proporsinya masing-masing. Pujian membuat remaja senang melakukan hal tersebut terus menerus. Perlu membuat remaja risih dengan perilaku buruk (Miskawaih, 1999: 76).

Pembinaan karakter dapat dimulai dari hal-hal kecil dalam kehidupan. Pembinaan karakter dimulai dari rumah tangga oleh para orang tua. Ibn Miskawaih mencontohkan saat makan di meja, ada tata cara yang baik perlu diajarkan. Orang tua pula yang berperan untuk menentukan pendidikan yang ditempuh anaknya. Ibn Miskawaih mengilustrasikan hal ini pada Raja-raja Persia yang bajik...mengirim anak-anak merekan bersama orang yang mereka percaya kedaerah yang jauh, di mana orang yang mendidik anak-anak mereka ini hidup keras, yang tidak pernah mengalami kemudahan dan kemewahan (Miskawaih, 1999: 81). Serta mengawasi lingkungan tempatnya bergaul. Lingkungan yang 
baik adalah lingkungan yang mengingatkan pada Allah SWT. Hindarkan remaja dari lingkungan buruk.

\section{G. Penutup}

Ibn Miskawaih pada dasarnya lebih dikenal sebagai filsuf moral dalam Islam. Hampir seluruh karyanya membahas tentang menjadi manusia yang baik. Kesempurnaan diri yang ingin dicapai melalui konsep-konsepnya adalah menajdi manusia filosof. Penanaman nilainilai moral dari filsafatnya mestilah melalui pendidikan secara bertahap. Baginya pendidikan dapat dikatakan baik jika itu sesuai mengarah kepada sumber otoritas AlQuran dan Hadis.

Kenakalan remaja sebagai salah satu bentuk pelanggaran dalam masyarakat dapat dibenahi melalui konsep yang ditawarkan oleh Ibn Miskawaih. Diawali dari penanaman rasa malu dimasa pertumbuhan anak-anak. Rasa malu bagi Miskawaih merupakan tanda berjalannya jiwa pikiran yang sejalan dengan aturan yang berasal dari Allah SWT. Jiwa pikiran ini jika tidak segera dibentuk dan dibina akan mengarahkan pada kenakalan remaja. Adapun remaja yang terlanjur sudah melakukan kerusakan pada dirinya dan masyarakat masih dapat dibina dengan cara seperti ini.

Setelah rasa malu sudah tertanam, selanjutnya pembinaan melalui syariat agama. Sebagaimana diketahui agama Islam selalu mengajurkan penganutnya untuk berbuat kebaikan. Ayat-ayat Al-Quran adalah kitab hukum moral yang perlu ditanamkan pada diri manusia. Tanpa pembinaan dengan nilai-nilai dalam syariat agama yang ditemukan adalah kerusakan pada remaja. Kerusakan seperti ini tidak hanya berdampak di kehidupan dunianya saja, tetapi juga dikehidupan akhiratnya. Disebabkan bahwa dunia hanyalah persinggahan sementara.

Maka agar pembinaan karakter ini berjalan dengan baik. Dibutuhkan pendidik yang memiliki nilai tambah dan pembeda. Maksudnya pendidik yang baik lebih mengutamakan pendidikan melalui perilakunya. Sikap dan tindakannya merupakan contoh yang tepat bagi orang lain. Tidak sekedar ucapan-ucapan yang menggugah. Remaja-remaja ini akan lebih cepat meniru apabila pendidik itu dapat menjadi figur. Sehingga dalam mengajarkan syariat agama pendidik ini sejalan dengan apa yang diajarkan. 


\section{DAFTAR PUSTAKA}

Ali, M. \& Asrori, M. 2006. Psikologi Remaja, Perkembangan Peserta Didik. Jakarta : Bumi Aksara.

Al-Syaibani, Omar Muhammad Al-Toumy,1979. FalsafahAt-Tarbiyah Al-Islamiyah, terjemahan: Hasan Lunggalung, Jakarta:Bulan Bintang.

Alavi, S.M. Zianuddin, 2003. Pemikiran Pendidikan Islam Pada Abad Klasik dan Pertengahan. Penerbit Angkasa, Bandung.

Arifin, Muzayyin, 2003. Filsafat Pendidikan Islam, Bumi Aksara, Jakarta.

Ihsan, Hamdani \& H.A. Fuad Ihsan, 1998. Filsafat Pendidikan Islam, Pustaka Setia, Bandung.

Fuhrmann, B.S. (1990). Adolescence, adolescent. London: Foresman and Company.

Hawari, Dadang. 1997. Al-Qur'an Ilmu Kedokteran Jiwa dan Kesehatan Jiwa, Yogyakarta: PT. Dana Bhakti Yasa.

Jalaluddin, 2001. Teologi Pendidikan. RajaGrafindo Persada, Jakarta.

Kartono, Dr.Kartini, 2010. Patologi Sosial 2 Kenakalan Remaja. Rajawali Press. Jakarta.

Miskawaih, Ibn, 1999. "Menuju Kesempurnaan Akhlak", Buku Daras Pertama Tentang Filsafat Etika, Penerbit Mizan, Bandung.

Willis, Sofyan S. 2008. Remaja \& Masalahnya. Bandung: Alfabeta.

Zuhraini, 1995. Filsafat Pendidikan Islam. bekerjasama dengan direktorat Jenderal Pembinaan Kelembagaan Agama Islam Departemen Agama. Bumi Aksara, Jakarta 